\title{
The institutional shaping of management: in the tracks of English Individualism
}

Dr Alistair Mutch

Professor of Information and Learning, Nottingham Trent University

Department of Information Management and Systems, Burton Street, Nottingham, NG1 4BU

Telephone: $\quad 01158482429$

Fax: $\quad 01158486512$

Email: $\quad$ alistair.mutch@ntu.ac.uk

Word count (including references): 10708

Alistair Mutch is Professor of Information and Learning at Nottingham Trent University. His most recent book, Strategic and Organizational Change (Routledge, 2005) is an exploration of changes in UK brewing between 1950 and 1990. As well as working on aspects of religious practice and their influence on the history of management, he is also interested in the application of ideas drawn from critical realism to the study of organizations. 


\section{The institutional shaping of management: in the tracks of English Individualism}

\section{Abstract}

Globalisation raises important questions about the shaping of economic action by cultural factors. This article explores the formation of what is seen by some as a prime influence on the formation of British management: individualism. Drawing on a range of historical sources, it argues for a comparative approach. In this case, the primary comparison drawn is between England and Scotland. The contention is that there is a systemic approach to authority in Scotland that can be contrasted to a personal approach in England. An examination of the careers of a number of Scottish pioneers of management suggests the roots of this systemic approach in practices of church governance. Ultimately this systemic approach was to take a secondary role to the personal approach engendered by institutions like the universities of Oxford and Cambridge, but it found more success in the different institutional context of the USA. The complexities of dealing with historical evidence are stressed, as is the value of taking a comparative approach. In this case this indicates a need to take religious practice as seriously as religious belief as a source of transferable practice. The article suggests that management should not be seen as a simple response to economic imperatives, but as shaped by the social and cultural context from which it emerges.

Keywords: management history; church governance; national culture

\section{Introduction}

In an age in which the impact of globalisation has raised important questions about the ways in which national cultures shape the actions of managers, then a deeper consideration of how we might approach the study of the shaping of such cultures and their enduring effects is important (Calori, Lubatkin and Very 1998; Ganter and Walgenbach 2002). Those associated with the comparative business systems approach, which seeks to explain divergence in economic action across national or regional boundaries, draw attention to cultural differences in understanding such divergence. In her comparative study of industry and society across Britain, Germany and France, Christel Lane (1995, 3) suggests that in Britain, '[f]irms are loose associations of lowly committed actors which, moreover, are exceptionally socially isolated.’ Another writer in the same tradition, Richard Whitley, $(2000,55)$ notes this and suggests that it cannot be understood without appreciating the historical development of a set of related institutions and 'the pervasive and long-established cultural norm of individualism'. In support for this latter contention, he uses the historical work of Alan Macfarlane (1978) on the English peasantry, The Origins of English Individualism, a book which has as its main focus the late Middle Ages. This suggestion is valuable both in recognising the 
importance of broadly cultural factors and in locating these materials in a longer timeframe than is often employed. However, in many ways the rather throwaway nature of this observation raises more questions than it answers. This article unpacks some of the questions that lie behind the use of historical work to explore the shaping of important sets of ideas. In this it contributes to a greater historical understanding of the cultural conflicts that shape the nature of modern management. In the rest of this introduction we consider in a little more detail some of the questions that a close reading of Whitley's source suggests.

Culture as a category in social analysis is relatively under-developed (Archer 1996). In particular, there is the problem of the focus on the development and impact of ideas relatively divorced from their social context. The paradigmatic case is that of religion and the rise of capitalism. Weber's work here has, of course, been widely influential but difficult to test satisfactorily in historical situations. In the most extensive discussion, Gordon Marshall argues that Weber demonstrated elective affinity, but not a causal link (Marshall 1980). His examination of the evidence from Scotland, a country with possibly one of the most thorough instantiations of Calvinist theology, suggests how difficult it is to find evidence of such a link. Other historians have followed from this to suggest that the link may be illusory and to switch their attention to, for example, the collective religious biography of business leaders (Brown 1997; Jeremy 1988). However, this discussion has remained at the level of ideas, on the congruence between, say, Calvinist theology and ideas of thrift and accounting. However there are clues in Marshall's work that suggest a homology between characteristic practices of church governance derived from Calvinist theology and organizational practice. This is notably in the institution of the 'Kirk Session', a body of 'elders' elected to run the church which will be explored in more detail in the main body of the article. We can set this insight in the context of more recent historical work which has developed the relationship of taken for granted practice to the development of broader ideas. In a sociological account of the formation of certain key figures of the Scottish Enlightenment, for example, Camic (1983) has argued for the need to look at certain shared experiences. In this such seemingly mundane matters as the organisation of teaching are argued to have contributed to the shaping of a particular way of looking at the world. In a similar vein, Muldrew's (1998) account of the development of institutions for credit in England over the period 1550 to 1720 depends on a detailed examination of mundane practices. It was the experience of litigation over debt, he argues, reaching as it did virtually every household from the 1580s, that led to changes in both institutions and ideas.

In an account that is particularly pertinent to the current topic, Dobbin $(1994,218)$ argues that the formation of railway policy in France, Great Britain and the United States in the nineteenth century should be 'located squarely in tangible social practices'. He places particular emphasis on practices that were held in each country to shape political processes by contributing to the maintenance of order. Dobbin's argument is that the ideas of economic efficiency that shaped railway policy were shaped by these practices, rather than being a pale reflection of economic imperatives. As such, they produced very different conceptions of efficiency and so different patterns of policy. The argument in this article is that there is equal value in exploring the institutional forces that shaped the 
emergence of conceptions of management. An exploration of such forces takes us back beyond Taylor and Scientific Management, although it might in its turn shed some light on that set of ideas. Whilst the texts produced by Taylor and others were vitally important in codifying sets of ideas, there are earlier precursors that are worthy of attention. In particular, there is a need to rediscover the emergence of management practices and the way in which they in their turn were shaped by to-hand practice and existing ideas about what was appropriate in the running of human affairs.

In doing this, we will engage in a little more detail with the implications of Macfarlane's work. Such an engagement demonstrates both the pitfalls of drawing on historical material and some of the interesting lines of enquiry that it opens up. The pitfalls in this case are the associations that Macfarlane's work has engendered. For an extremely controversial work at the time of publication it has inspired remarkably little subsequent work and is ignored by a large number of historians, including many who take English identity as their central concern (e.g. Colls 2002). However, it is endorsed enthusiastically by a small number of historians, particularly those with a broadly conservative agenda. Here, for example, is David Starkey in a recent interview commending Macfarlane's 'remarkable' book in the context of an assertion that

England, unlike its Celtic neighbours, has a world historical dimension. I am interested in the shaping of a type of polity and in attitudes to property, to personality, to law, which seem to me to be unique to the Anglo-Saxon world and its diaspora into America, Australia, Canada (Neale 2004, 21).

When one sets this alongside the argument that 'Monarchy is the natural and universal form of government. Everything else is an aberration' (Neale 2004, 21) one can see the need to draw on historical work carefully. A reading of Macfarlane and his critics suggests that, whilst some of his claims might not be supported by the evidence, notions about the historical continuity of institutions are interesting and thought provoking. However, they do indicate the dangers of looking for some form of 'origin', as opposed to exploring the unfolding of ideas and institutions over time.

In doing this, we can draw on another form of contrast that Starkey makes explicitly (if in crude and mistaken terms) and that Whitley tends to overlook. This is that, in a discussion of British management, Whitley draws on a work about English individualism. Now, this might be regarded as a simple slippage between England and Britain that is all too common (see Ransome 2005, 169 for another example). However, rather than regarding this as unfortunate or irritating it can be productive to work this contrast a little further. In this article the contention is that indeed what is meant by individualism is derived from the particularly English conception of the 'gentleman' (and hence 'gentlemanly capitalism' (Daunton 1989)). Dobbin suggests that conceptions of the sovereignty of elite individuals shaped the formation of British railway policy, but it is noticeable that his discussion slips without pause between the terms 'English' and 'British' (Dobbin 1994, 159). However, remembering that there were other parties in the enterprise that was Britain, and that many have argued that the ideas referred to by Starkey were actually Scottish products, there is merit in examining the contrast between 
Scottish and English developments (Herman 2003; Buchan 2003). In particular, this article argues that there is merit in contrasting an essentially personal approach to authority and responsibility in England to a more systemic perspective in Scotland.

The article begins by a closer examination of the Macfarlane thesis. In this we are concerned to set the work in its broader historiographical context. Critiques of the evidence on which the thesis is built are reviewed to indicate that the questions that Macfarlane raises are indeed of some relevance. We trace two implications for the study of management. One, which is treated fairly briefly, is the formation of the myth of the 'free born Englishman'. Rather more time, however, is spent on the formation of institutions of state administration. The importance of the locality and personal responsibility in England is stressed, based on a discussion of the rise of the gentleman. The implications of this for church governance practices are then explored, in order to contrast them to the very different approach adopted in Scotland. This focus on practices of church governance is important when we come to look at the evidence for a number of Scottish innovations in management practice in the late eighteenth and early nineteenth centuries. These innovations are discussed in the context of a number of factors, all of which suggest this powerful contrast between personal and systemic authority. However, the English gentlemanly model triumphed and so we come to a position of giving some support to Whitley's contention. We have done this, though, via a route which suggests contradiction and conflict in the development of ideas. It is one which suggests that institutions, (and one suggestion in the context of England is that this might be centrally the educational institutions represented by Oxford and Cambridge), were powerful barriers to the adoption of ideas that thrived in other institutional settings.

\section{Macfarlane: politics, evidence and implications}

Alan Macfarlane's The Origins of English Individualism provoked a considerable debate on its publication in 1978. His thesis that a 'classic' peasantry had never existed in England was seen as a considerable challenge to, in particular, Marxist accounts. If the classic peasantry had never existed in the homeland of capitalism, a homeland which provided the historical evidence for Marx's work, then the debates on the transition from feudalism to capitalism were rendered at a stroke irrelevant. However, despite the immediate flurry of response the work has not, as French and Hoyle (2003) note, provoked any school or programme of research and remains strangely neglected by many. As we have noted, there is currently considerable interest in the historical formation of English (as opposed to British) identity, but Macfarlane's work plays little if any role in this debate (Robbins 1998). Even in those works which place considerable emphasis on the notion of continuity in the development of English institutions, such as Clark's (2000) important historiographical essay, Macfarlane does not appear. His work is, however, valued by some of those who have argued for the importance of the continuity of institutions from the Anglo-Saxon polity into the imposition of Norman rule. In pointing to the value of MacFarlane's questions, for example, one of the most prominent advocates of the continuity thesis, James Campbell, argues that 
The nature and origins of the English state, the mysteries of its long continuity and power, are truly interesting, and not simply for us alone, for that state and those institutions have not been without their influence on the world at large (Campbell 2000, 258).

Once again, we catch echoes of the agenda that Starkey espouses, echoes that suggest that this debate needs to be handled carefully. In exploring it we look briefly at the Macfarlane thesis and the latest reviews of the evidence before considering some of the deeper implications.

MacFarlane's case for the enduring difference of England rested in large part on arguments about the existence and nature of a peasantry in medieval England. Macfarlane's argument was that, using records of landholding, he could demonstrate that English 'peasants' were capable of and did alienate land. This he contrasted to what he took as the 'classic' model of the peasantry in which land was the possession of the family not of an individual and in which the imperative was to 'keep the name on the land'. His argument was

that the majority of ordinary people in England from at least the thirteenth century were rampant individualists, highly mobile both geographically and socially, economically 'rational', market-oriented and acquisitive, ego-centred in kinship and social life (Macfarlane 1978, 163).

It is fair to record that Macfarlane himself notes that his argument is a speculative and provocative one. In many ways it reads like a series of promissory notes to be cashed in against future research, research which never transpired. However, the book does rest on documentary evidence taken largely from the Essex parish of Earls Colne, supplemented by work on the Westmorland parish of Kirkby Lonsdale. This work consisted of the analysis of records of land tenure, especially 'copy hold' leases. This was a form of land tenure which, Macfarlane argued, gave landholders considerable privileges and control over their land. Using computing power that was not available to Macfarlane, French and Hoyle have revisited this material and argue that 'the transformation in the land market which Macfarlane commented upon may be no more than a figment of his statistics' (French and Hoyle 2003, 603). They note further that not only does the evidence drawn from copy hold tenure not support Macfarlane's argument, but also that copy hold tenure only accounted for a fraction, albeit a substantial fraction, of land held in the parish. From this they conclude that the detailed thesis of English Individualism, on the nature of land tenure, 'is refuted'. However, it is important to note that they also acknowledge '[i]n another respect, his position may be said to have been reasserted. As a description of people's rights, English Individualism is surely accurate' (French and Hoyle 2003, 621).

The second form of critique relates to Macfarlane's characterisation of the peasantry. His sources for the formation of the peasantry were derived largely from eastern Europe and placed a heavy emphasis on land tenure and community. The critique, developed in particular by Jane Whittle (2000), is that this definition of a 'classic peasantry' is misleading. She argues that the defining characterisation of peasant farming is 
subsistence rather than land ownership. Macfarlane’s argument, she suggests 'is based on an unusually restrictive definition of peasant society and economy, stressing an almost total lack of market relations in peasant societies' (Whittle 2003, 13) When he then finds such market relations he is then able to argue that by definition there cannot be a peasantry. By contrast Whittle argues that her detailed examination of the rural economy of Norfolk suggests that conceptions of individual property were consistent with peasant farming. 'Only when', she argues 'these landholders became heavily reliant on hired labour, on the selling of their produce on the market, and on the purchasing of the necessities of their subsistence, should we declare them capitalist' (Whittle 2003, 89). This evidence suggests then that Macfarlane was looking in the wrong place, but not that he was completely wrong. Of particular importance, although not developed in his account, are the generation of ideas about the 'free born Englishman', to which we will return. However, if landholding was not the central issue that he would make it, his focus on Anglo Saxon influences might be significant for us in another direction, that of the institutions of state.

Macfarlane concludes his book with a suggestion that the origins of the individualism he claimed for the English might well be found in the forests of Germany. His tentative argument, but one built on a long tradition in English historiography, was that the distinctive features he was discussing were brought into England by Anglo Saxon invaders. (We should note in passing here that this thesis is challenged from, as it were, 'the other side'; that is, there are those who would argue that the impact of the Anglo Saxons itself has been exaggerated (Pryor 2004). These advocates of continuity in the historical record and of the persistence of the 'British' (and hence the 'Celtic') in England have problems with the nature of the evidence available, which has to draw extensively on archaeology rather than history, but it is as well to remember that the Macfarlane thesis is a much contested one).We have already seen that some scepticism has been expressed about the nature of the Anglo Saxon contribution, and that MacFarlane's thesis as regards forms of land tenure might be questionable, but there is possibly more of value in exploring the construction of institutions of governance. Colls, for example, notes that Norman institutions of justice were built on Anglo Saxon formations such as the hundred and the shire (Colls 2002; cf. Hollister 1986). This argument tends to diverge in two directions. One is the notion of the 'free born Englishman', which we review briefly. The second, which we explore in more depth, is the notion of the continuity of institutions of state governance. We pursue this latter suggestion in more depth as it is such institutions which we will argue formed part of the formative context for the development of modern ideas of management. However, it is possible to argue that the linked notion of the 'free born Englishman' could also have a powerful impact on forms of management, particularly the persistent emphasis on external contracting (Jones 2000).

\section{England and Scotland: institutions and practices contrasted}

The notion of the 'Norman Yoke' has been most recently reviewed in a series of popular essays by Michael Wood (1999). It continues to form an important element in aspects of popular culture, notably in the various retellings of the Robin Hood legend. It is that the 
rights of the English people were violated by the Norman invaders and that these involved certain rights of democratic involvement. In this form, the Norman Yoke, as most vividly demonstrated by Christopher Hill (1958), was a powerful rhetorical device for the radicals of the seventeenth century. In this form the 'truth' of the myth, as with all myths, was of rather less import than its mobilisation. However, the work of Faith (1997) (another writer who does not mention MacFarlane at all) presents a more nuanced account which, whilst recognising these foundations, also presents the sense of change and loss. She argues that prior to the Conquest and 'in contrast with France', 'a large proportion of the peasantry and smaller landowners played an essential role in the state which preserved for them a large measure of freedom and independence (Faith 1997, 88). However, under occupation such rights became, she suggests, attenuated. In particular, she notes 'A common way of administering a monastic estate came to be to assign the revenues from particular manors to individual officers of the community or to the department of the house which they administered' (Faith 1997, 182). This meant an increase in those landowners interested in maximising returns from the land and so an increase in the regulation of the peasantry. This was the source, she argues, of a loss of direct involvement on the part of the vast mass of the populace in the institutions of government. However, this was never entirely complete and the memory was never entirely erased. This then was a material basis for the continuing emphasis on the 'free born Englishman', an emphasis added to over the years. The great Scottish writer Hugh Miller noted in his impressions of his travels in England a particular stubborn independence that he found wanting in Scotland (Miller 1853,377). He related this to the character of church governance in observations which have a bearing on our later discussions. In Scotland, he argued, religious Dissent always took a presbyterian form (Miller 1853, 394). That is, regardless of the nature of the theological dispute, the form of governance adopted was always that which mirrored the host church. In England, by contrast, Dissent led to the multiplication of independent churches: 'The country of insulated men is the best fitted to be also the country of insulated Churches' (Miller 1853, 397). This led him to the general observation, to which we will also return, that 'The Englishman stands out more separate and apart as an individual; the Scotchman is more mixed up, through the force of his sympathies, with the community to which he belongs' (Miller 1853, 395).

This distinction draws our attention to a key point of contrast between the two countries. Whilst accounts of the formation of Britain have stressed a common Protestantism, the differences between the forms adopted are of some significance (Colley 2005; Robbins 1988). Clark (2000, 274) has argued that when looking at England 'Anglicanism, not Protestantism, should be our key term' and this will have some significance at the end of our second, and longer discussion, that on the rise of institutions of state governance. As Hollister has argued, the Norman rulers built a remarkably successful administrative state, more efficient and powerful than others in operation in medieval Europe but this built on Anglo Saxon foundations. As he notes

The Anglo-Saxon royal administration, which William had seized and perpetuated, was more effective still. As ruler of England the Conqueror inherited a well-articulated system of shires and sheriffs, shire courts and hundred courts, 
and at the center an ambulatory royal entourage that exercised an unusual degree of control over the kingdom's military and fiscal resources (Hollister 1986, 223).

What is of particular importance here is the local character of this administration, something which was built on as administration increasingly passed from clerical to lay hands and the office of commissioner of the peace was successfully created (Morgan 1986). It is interesting at this point to return to our contrast with Scotland. For the success of the Normans and later rulers in creating an effective state, which rested on local representatives and a centralized bureaucracy was both in stark contrast to Scotland and could also, it is suggested, have institutionalised a particular set of practices which centred importantly on the personal responsibility of what would evolve to become the English gentleman. Scotland, by contrast, was a profoundly lawless country with a weak central administration. In exploring the very different form of church governance in Scotland, Margo Todd suggests a connection with these patterns of state administration which is worth citing at some length:

A crucial difference was that in Scotland, sessions had powerful patrons, even in conservative towns and in the countryside where most people lived. The men with power - lords and lairds, substantial burgesses and landward proprietors - had a need for the sessions' services that was not so pressing in England. There, where power had been effectively centralised for centuries, and where an efficient system of JPs had carried out the royal will since the fourteenth century, enforcing a common law and administering a relatively uniform code of order throughout the realm, it was less clear that there was a vacant slot for the sessions to fill. In comparatively decentralised Scotland, however, long plagued with royal minorities and weak monarchs, and without an effective system of JPs until the later seventeenth century, there was a crying need for a mechanism to impose order and uniformity in the localities. What the heritors [major landowners] found in the sessions was an idea whose time, in Scotland, had come. The timing was the more fortuitous because it coincided with the expansion of small proprietorships resulting from the feuing movement ${ }^{1}$ : an emerging category of new landholders anxious for a greater voice in administering local affairs found a natural outlet for their ambitions in kirk sessions (Todd 2002, 408).

It is necessary to explain what was so different in the Scottish settlement. Whilst this has been discussed frequently in terms of doctrine, what we are more interested in here are practices of church governance. In the reformed Kirk there was an important role for the Kirk Session. A body comprised of a small numbers of elders, formally elected for life by the congregation, this body possessed and exercised considerable powers of discipline over both minister and congregation. In turn they were responsible to local presbyteries. From here representatives were sent to a General Assembly, which exercised the supreme power of church discipline, discipline which could be fearsome in its consequences in the earlier years. This system was also characterised by extensive record keeping, as only those members of the church in good standing were allowed to partake of communion. This system gave rise to a distinctive set of practices of accountability which we can contrast with the English position. We will do this to further build up the case for a 
distinctively personal sense of authority in England, which may form part of the cult of individualism that we have been examining.

In his revisionist account of the English reformation, Eamon Duffy (1992; 2001) (yet, again, another historian concerned with key aspects of English identity who does not mention MacFarlane) argues that the Reformation ought to be seen as a state sponsored movement which was profoundly against the wishes and desires of the great mass of English worshippers. Whatever our views of this case, what is interesting for our discussion is his focus on the shifts in church governance that the Reformation brought. He presents a case which sees the laity as having a profound role in church affairs, not through any influence on doctrine but through their financial support for the fabric of the church. This was expressed in the form of parts of the church fabric and their associated decorations supported by particular sections of the community. Thus he points in Morebath to the institution of the 'church sheep', in which a flock of sheep was kept whose profits were dedicated to the maintenance of the church (Duffy 2001). The keeping of this flock was a collective obligation, with individual animals assigned to run with parishioners' flocks and to be accounted for at regular occasions. In pointing to this collective activity, Duffy is perhaps (although clearly this is a point never explicitly considered) providing evidence to point to the limitations of Macfarlane's account. That is, perhaps too much can be made of the individual nature of material factors like land tenure as opposed to the collective dimension of cultural practice. However, what Duffy argues for is the destruction of this collective form of support and the individualising of it in the form of new practices of church governance, central to which was the office of church warden.

The detailed practices of this office are little examined by historians, but the evidence that we possess suggests a powerfully individualistic conception of the post (Mutch 2005a). There were generally two wardens, one the representative of the vicar, the other nominally elected by the congregation. Compared to the Scottish practice, these officers were generally elected for an annual term, although this could be extended in some circumstances. Their accounting practice seems to have been a distinctly personal one, with them having been responsible for all income and expenditure during their term of office. Whilst they presented a form of account at the end of their term, during their term they would seem to have made up any temporary short fall from their own pocket, thus restricting their ranks to the 'middling sort'. Such practices meant that a tradition of detailed management was not fostered, as the basis for such accounting was not present. Of course, those occupying the office tended to be the 'middling sort' in the parish, rather than the landowners, but in their personal occupation of office they paralleled features of the emergence of 'gentility' amongst their superiors. In particular, a key feature was the personal responsibility for office, a responsibility which would be fulfilled because of the holding of a set of gentlemanly values, not because of any detailed accountability. An important factor in the consolidation of this was the development of particular forms of education amongst the gentry. Heal and Holmes, for example, note that '[b]y the midsixteenth century the best secondary education for boys, whether conducted in household or school, was determinedly classical and a deliberate preparation for higher education' (Heal and Holmes 1994, 259). Training in the sort of numerical skills useful for entry to 
business was restricted and not regarded as appropriate for estate management until the eighteenth century (Whyman 1999, 83). In returning to Clark’s point about the importance of Anglicanism to this complex of ideas we can usefully cite the Anglican perspective on authority and accountability provided by the Bishop of Gloucester, William Warburton, who argued in 1766 that

All places of honour and profit, in the magistrate's disposal, are not there in the nature of a trust, to be claimed and equally shared by the subject; but are of the nature of prerogative, which he may dispose of at pleasure, without being further accountable, than for having such places ably supplied (cited in Torrance 1978, 71).

However, this is where England and Scotland diverged to some extent. The results of this divergence can be seen in Adam Smith's disdain for his time at Oxford. He won an Exhibition to support attendance at Balliol College in 1740 but found it full of 'exploded systems and obsolete prejudices' (Buchan 2003, 123). His unfavourable comparison of his experience of the English system to his time at Glasgow University indicates the extent to which the two countries had diverged and goes some way to explaining the particular contribution of Scotland as junior partner in the Empire to supplying a cadre of administrators (Skinner 1979). However, this supply in its turn was not immune to accommodation to the demands of 'gentlemanly capitalism' and we can explore these tensions by looking at some Scottish contributions to the development of management. These placed, it will be argued, a particular stress on systemic forms of accountability, a stress that we can relate to distinctive forms of Scottish practice.

\section{Scotland and management}

The purpose of this section is not to give extensive detail on Scottish management practice, but to supply sufficient evidence to suggest both the importance of the contribution and its distinctive nature. We can point to a number of such contributions, from state administration through estate management and management texts to business practice. In the former area, there is the contribution of Charles Middleton, later Baron Barham and 'the best British naval administrator since Samuel Pepys' (Moody 1975, 140; Morris 2004). At the end of the eighteenth century, together with fellow Scot John Fordyce, he introduced radical administrative changes to the Navy which, as Rodger (2004) reminds us, was the most significant industrial enterprise in eighteenth century Britain. The rural economy was also, of course, central to development and Eric Richards and Monica Clough's (1989, 324) account of estate management on the lands of the Earl of Cromartie argues that 'Land agents were the lynchpin of the managerial class which emerged strongly during British industrialisation’. These land agents were heavily influenced by lowland Scots (Spring 1963). Men like James Loch, agent for the Sutherland estates and Francis Blaikie, steward to the pioneering Holkham estate in Norfolk, were widely called upon for advice and held up as models of advanced practice (Richards 2004; Parker 1975). However, more central to our concerns are those who operated in the developing industrial sector. James Montgomery, manager of the cotton 
mill of MacLeroy, Hamilton \& Co. in Calton, Glasgow, published in 1832 The Carding and Spinning Master's Account or the Theory and Practice of Cotton Spinning, leading him to be considered by some to be 'the first management theorist' (Gantman 2005, 24). Another Glasgow publisher, W and W Miller, published in 1834 George Galbraith’s The Cotton Spinner's Companion. This concentration of practical advice for the newly emerging managers of the cotton industry echoed an earlier tradition of the production of accounting text books. In 1736, for example, John Mair, a school master at Ayr, produced Book-keeping Methodiz'd, which ran to nine editions (Mepham 1994). Its successor, Book-keeping Moderniz'd in turn also ran to nine editions between 1773 and 1807. It was the dominant accounting text of its day, being used extensively in America as well as in Britain. He was not alone in his endeavours: Robert Hamilton also produced a number of texts, including An Introduction to Merchandize (1777). However, the activities of Scots were not confined to publishing; their innovations were also in the world of practice. For example, there was Andrew Wedderburn, a member of the Governing Committee of the Hudson Bay Company in 1810 (Spraakman and Margret 2005). There he introduced new accounting practices which, with their emphasis on detailed accountability and individual responsibility for income and expenditure prefigured, argue Spraakman and Margret, practices which are more closely associated with developments in the United States over 150 years later. Similar practices were introduced into the rival North West Company at the same time Edward Ellice, the London born but Marscihal College, Aberdeen, educated son of an émigré Scot. Another successful Scottish emigrant who developed managerial practices which were ahead of their time was Andrew Barclay Walker (Mutch 2006). The son of a Scottish brewer, Peter Walker, who moved from Ayrshire to Liverpool in the 1840s, his partnership with his father dominated the streets of Liverpool. The public houses of Peter Walker \& Son were distinctive in that the majority were run by salaried managers, as opposed to tenants. The latter was the dominant practice across England and Wales when brewers owned pubs (Scottish pubs being largely tied by loan, rather than by ownership). From the 1850s Andrew Walker recorded the performance of his pubs in considerable detail, constructing annual profit and loss accounts for each pub. As his empire expanded, he employed 'inspectors' to ensure that his strict rules were adhered to, overseen in their turn by a 'superintendent' who reported to the general manager. This construction of a managerial hierarchy with clear rules for conduct and supported by detailed accounting information was an important precursor to the development of multiple retail chains (in which, of course, Scots such as Thomas Lipton played a key role). Walker's innovations became common practice in Liverpool, although fiercely resisted in other parts of England. ${ }^{2}$ They also produced the wealth and influence that led to him becoming twice Mayor of Liverpool, and which left tangible evidence in the form of the Walker Art Gallery and the Walker Engineering Laboratories at the University of Liverpool.

This last example suggests something of a distinctive Scots contribution, based on detailed record keeping. Mepham (1994, 276), for example, argues that Hamilton's 1777 book was 'much in advance of its time, with an emphasis on the managerial use of accounting information which is absent from the other eighteenth-century books.' This detailed focus on accountability through information characterised the work of James Loch. 'He proposed', Spring $(1963,93)$ reports of his work for Lord Egerton, 'that the 
administration be divided into distinct departments; that the profit and loss of every unit, down to the last coalpit, be clearly accounted for; and that agents be allowed to keep in their hands only such moneys as were remitted to them for authorized expenditures.' The innovations that Wedderburn introduced to the Hudson Bay Company were designed to ensure the detailed accountability of every trading post. The earlier work of Middleton and Fordyce had also placed a similar importance on the importance of documentation. Under the existing system

On every Change in the Office of Surveyor of the Woods which has happened during the present Century, the Surveyors General, or their Representatives, have retained all the Official Books and Documents which the Officer happened to be possessed of. Thus, all the Benefit arising from past Experience has been lost; no Consistency of Proceeding has been observed; and each new Surveyor, beginning without Information or Guide, had adopted whatever Plan of Management happened to suit his Fancy (Lambert 1975 [1793], 460-1).

Documentation, therefore, was not only necessary to establish the rights of the Crown, but was also in a positive sense necessary in order to learn from experience. In his first report as Surveyor General acting on the acceptance of the report, Fordyce laid particular stress on his efforts to secure a safe home for the surveys, plans and other documents that had come into his care (Lambert,1975 [1797]).

It is tempting to see this evidence for a distinctive Scottish practice of management, one based on detailed record keeping to facilitate individual responsibility in a carefully drawn chain of command, in the context of the Scottish Enlightenment. However, the connections appear to be tenuous at best. Many of the key figures of that movement were ambivalent, at best, about the impact of commerce (Broadie 2001; 2003). Adam Smith, who did not share this ambivalence, was deeply suspicious of the employment of managers. Business was best conducted, he argued, by owners rather than by agents, a view which was widespread and influential throughout the $19^{\text {th }}$ century. Indeed, Middleton and Fordyce were forced to tackle this head on in their administrative reforms of the woods in the hands of the Crown. They begin by recognising Smith's (in their opinion 'the Writer of far the greatest Authority on the Subject of Political OEconomy') argument that the Crown lands could produce far more if in private hands (Lambert 1975 [1792], 33). The Commissioners raised a number of practical problems with such a step, but recognised that private ownership provided the closest and best model, recording that 'The nearer the Management of Public Property can be brought to that of private Property, the greater, we are persuaded, will be the Advantages to the Public' (Lambert 1975 [1792], 35). To this end they consulted with the agents and surveyors of great private estates with a view to obtaining models of best practice. The report therefore represented something of a contradiction between Smith's uncompromising hostility to any thing other than the direct involvement of the owner in management and the need to run a large national enterprise which demanded a long term perspective in order to safeguard timber supplies of strategic importance. The Enlightenment is better seen as a favourable intellectual context, given its emphasis on practical reasoning from careful observation. Of particular significance is the Scottish emphasis on careful recording and 
publication of results. Thus in 1755 the first systematic census of population attempted in Britain was carried out by Alexander Webster, an Edinburgh clergyman (Buchan 2003). The full flowering of this concern was the remarkable series of descriptions of every parish in Scotland published in the Statistical Account of 1785 organised by John Sinclair. It is of particular interest to note that the entry in the Statistical Account for the parish of Bowden was 'Drawn up by a Friend to Statistical Inquiries, from Materials chiefly furnished by Mr Andrew Blaikie, Tenant in Holydean', the father of Francis (Statistical Account 1795, 230). This suggests the involvement of the 'middling sort' in this process of inquiry and publication. Three factors seem important here: publishing, education and Presbyterianism.

There was a strong tradition of the writing up of existing practice for use elsewhere. There was also an infrastructure of printers and publishers, with Robbins noting the Scottish domination of the means of knowledge transmission (Robbins 1988, 157). Montgomery's Account was published by the Glasgow bookseller John Niven, who specialised largely in books on Presbyterianism. However, he was also the publisher in 1824 of Robert Brunton's A Compendium of Mechanics, or Text book for engineers, millwrights, machine-makers, founders, smiths, \&c, which also ran into several editions. The publisher of Galbraith's Companion was, intriguingly, also a publisher of Chartist tracts which, given the early involvement of Andrew Carnegie in Chartism suggests connections which deserve further exploration. ${ }^{3}$ Francis Blaikie, the Holkham steward, was the writer of a number of pamphlets on agricultural matters; he considered 'it a duty incumbent upon man to diffuse to his fellow-men the fruits of his experience in this life. All men have not the same advantages of acquiring information. Those advantages are bestowed upon us by the providence of God' (cited in Parker 1975, 134).

Such productions, of course, depended on an audience capable of and willing to respond to their advice. In his observations on the advanced state of agricultural improvement in Blaikie's home county of Roxburghshire, the Reverend David Ure pointed to the importance of the four libraries maintained by public subscription. 'Owing in a great measure to these literary collections,' he argued, 'the farmers generally have a turn for reading; their minds are opened for every kind of improvement, and are divested of unworthy prejudices: they reason with accuracy on a variety of topics, and they add theory to practice, in the different parts of husbandry and agriculture' (Ure 1794, 78) Such capacity in turn demanded at least basic levels of literacy, but the Scottish education system produced more than this for certain groups. There are debates between Scottish historians about the extent to which Scotland's much vaunted education system did indeed facilitate the growth of the 'democratic intellect', with a clear line by which the 'lad of parts' could rise from local elementary school to university education. However, whilst provision might be lacking for the urban working class, for the prospective entrepreneur, manager, or administrator the education provided was well suited (Anderson 1985). In particular the emphasis on book keeping was of considerable importance. John Mair developed book-keeping at Ayr Academy, where the subject had been introduced in 1716 (Strawhorn 1983). By the time Andrew Walker attended the school the rector was Doctor Memes, who was heavily involved in local affairs, such as the practical arrangements for a piped water supply and attracting the railway to the town. 
There was, then, an emphasis on practical skills, skills which could be available to those from a range of backgrounds. James Montgomery was able to rise to the position of manager in the cotton mills where his parents worked. Most of our managers ended their education at this level, what we would probably call a sound elementary education (although the detailed evidence is not available), but we have seen that Edward Ellice attended university in Aberdeen. James Loch, too, attended university in Edinburgh, but these were men from rather more elevated social origins. However, it would seem that the education system did not channel the committed and able into the more classical channels of learning that were so roundly condemned by Adam Smith after his unsatisfactory time at Oxford.

Of course, the emphasis on publishing and education can both be seen to owe much to the Presbyterian form of religion (Rosie 2004). Several of our pioneers exhibited their adherence to this form of belief. Whilst Charles Middleton was a member of the Church of England on his marriage in 1761, his strong Evangelicalism seems to have been profoundly shaped by his experience of Scottish Presbyterianism (Moody 1975). According to his entry in the Dictionary of National Biography, James Montgomery 'retained strong Presbyterian convictions but was recalled as tolerant of others' (Jeremy 2004, 859). Francis Blaikie returned to his native Borders in 1832 and lived through the Disruption. His will contains bequests to the Free Church ministers and congregations of Melrose and Bowden, suggesting his involvement in church affairs (Blaikie 1857). Andrew Walker in 1866 took up a share in St Andrew's Church of Scotland in Liverpool and joined its Committee of Management (Mutch 2005a). As we have seen, the forms of governance of the Presbyterian church as established in Scotland placed considerable emphasis on individual accountability within an overall system supported by detailed record keeping. What is important here too is the broader sense of system. Here we can return again to Miller's observations, where he suggests that Scots were more prone to think in terms of larger systems:

The insulating bias of the English character leads to the formation of insulated Churches; whilst this aggregate peculiarity of the Scottish character has a tendency at least equally to bind its congregations together into one grand Church, with the area, not of a single building, but of the whole kingdom, for its platform. ...An Englishman might have thought of gathering together a few neighbours, and making a Church of them; the Scotchman at once determined on making a church of all Scotland (Miller 1853, 399)

Lest this be thought to be of merely historical significance, given the decline in organised religion in Britain generally, and falling membership in the Presbyterian forms of religion in Scotland in particular, commentators on the current state of national identity in Scotland also point to the continuing influences of taken for granted practices that have been shaped by this Presbyterian legacy. David McCrone argues that 'people think of themselves as Scottish because of the micro-contexts of their lives reinforced by the school system' (2005, 74). We have argued that chief amongst these micro-structures in forming a distinctively Scottish approach to management were church governance practices. However, whilst such approaches are interesting, the argument is not that they won out. Rather it was the English model of gentlemanly individualism which continued 
to dominate. In our conclusion, we can suggest why this might have been so and point to some implications of our discussion.

\section{The search for individualism: tasks and possibilities.}

In assessing the impact of the ideas we have discussed, we need to recognise that many of these pioneering ideas fell on stony ground. In brewing, for example, Andrew Walker's use of managers to run his public houses was widely resisted, both by licensing magistrates and by other brewers (Mutch 2006). One reason for this was the nature of the development of industry and commerce in a first mover economy with strong existing traditions (Jones 2000). These traditions, reinforced by the emphasis placed by political economists such as Smith and Mill on the direct personal involvement of owners in the affairs of the firms, meant the continuing attachment to networks of agents and contractors. This emphasis on personal involvement meant that even when there was a lack of interest or ability in continuing involvement in business on the part of the next generation, managers drawn from outside were rarely considered (Law 1995). Instead, managers remained the product of experience rather than education and tightly tied to the fortunes of both family and firm. In turn, we have to recognise the lack of institutions for the diffusion of the management practices propagated by the Scots. There was a culture of localism and secrecy about much business practice, with the issues being discussed being those of broader political economy rather than management practice.

Of course, there was also a degree of hostility towards ideas propagated by Scots. In an echo of contemporary debates, the hard-headed focus of Scots political economy on the centrality of the market seemed narrow to those concerned with broader issues. Keith Robbins $(1988,132)$ notes the sneering comments in 1842 that '[i]t is especially in mediocrity that the Scotch are great', Scots being 'first-rate second-rate men'. Hugh Miller himself admitted that in terms of intellect Scotland had not produced thinkers of the first rank, despite all the achievements of the Scottish Enlightenment (his comparators being Shakespeare, Milton and Newton) (Miller 1853, 370). In practical terms, he recorded the observation of one of his landladies that 'the Scotch became overseers and book-keepers, sometimes even partners in lucrative works, and were usually well liked and looked up to' (Miller 1853, 70). The rather Olympian attitude on the part of some English commentators towards the mundane matters of practical administration at which the Scots seemed to excel was compounded by the continuing importance of Anglicanism in religious life and farming in economic life. Anglicanism retained the rather gentlemanly view of administration which placed emphasis on individual characteristics of trust rather than on systems of accountability. It was not, either, that all our Scots were immune to these charms. Andrew Walker, for example, on acquiring the Derbyshire country estate at Osmaston spent considerable sums on restoring the parish church and was buried at the Anglican church at Gatecare, near his Liverpool house. His sons followed the classic patterns of the English gentlemen with education at Harrow and Rugby. They did carry on the family business, but without much conviction. Their 
interests were more in country pursuits, with their attention to their Scottish roots being restricted to the size of their kills on the grouse moors.

The retreat by Walker to the country estate was a familiar one for those successful in business. The continuing importance of the tenancy model of farming on such estates on both sides of the border may have reinforced the emphasis on personal accountability. In addition, the association of administrative efficiency with Scottish land agents may not have been a particularly strong selling point for manufacturers opposed to continuing aristocratic power. As Checkland notes of Loch 'as a middle-class professional man whose life was given over to conserving his master's assets and maximizing their earning power, [he] had to do so under a nobleman whose spending was not far from feckless' (in Richards 1973). For a number of reasons, therefore, it seems that the pioneering efforts of Scottish management practitioners and writers may have had relatively little impact within Britain. Their main success may have been in the very different institutional and cultural setting of the USA (Grey 2005). Thus, James Montgomery’s books were influential in the development of the cotton industry in South Carolina; he moved there to manage cotton mills after moving from Glasgow to manage a cotton mill in Maine (Jeremy 2004). Daniel Craig McCallum who emigrated from Scotland in the early nineteenth century is credited by Chandler with devising the first organization chart at the Erie Railroad (Chandler 1962). These precursors of systematic management deserve more attention as paving the way for and shaping later management practices and theories.

We have thus arrived at a degree of support for Whitley's assertion about individualism, but have found that the nature and development of this individualism was a complex and conflictual process. This suggests that scholars of contemporary organisations should exercise a degree of caution in co-opting historical work to support their arguments. We have noted that the particular work that we have examined, Macfarlane's English Individualism is both unfairly neglected but also championed by those with a broader agenda. We may have our own views on the nature of that agenda, but we need to see historical works in their broader historiographical context if we are not inadvertently to be drawn into positions which we might not share. However, what an examination of that work indicates is not only the dangers of a search for 'origins' but also the value of tracing the unfolding of sets of ideas and practices over time. This article has suggested that in such an unfolding we need to pay careful attention to seemingly mundane practices. This insight emerges from the contrast between Scottish and English contributions to the British enterprise, suggesting that a key tool in the development of a better understanding of the cultural dimensions of management is a comparative approach. The evidence presented here perhaps helps in understanding the findings of another comparative study, one which noted the emphasis of British managers on 'manmanagement' as opposed to the technical focus of their German counterparts (Ganter and Walgenbach 2002). This can unite the twin themes of local systems of gentlemanly state administration and the sturdy independence of the 'free-born Englishman'. In turn Calori, Lubatkin and Very's (1998) comparison of the formation of French and British managers points to the importance of early education. If we pursue our comparison of Scotland and England a little further we can draw attention to the powerful influence of Oxford and 
Cambridge in prompting a model of educational practice right through the English education system. This influence can be argued to perpetuate a model of the gentlemanly formation of character. In a magnificent discussion of the representation of universities in fiction, Ian Carter (1990) draws our attention to an alternative Scottish tradition which perhaps has resonance for more contemporary discussions about the nature and purpose of management education. It is hoped that the argument presented in this paper, with its focus on the comparative analysis through time of the mutual interplay between ideas and taken for granted practice has provided a means of developing this debate further. This ought to have resonance beyond a mere 'local' debate, particularly given the recent interest in the shaping of many American practices by ideas drawn from Scotland (Herman 2003). As more management practices are drawn into question by globalisation, then historically informed studies of the shaping of key management practices and ideas ought to prove valuable.

As Whitley points out, many accounts of management are functionalist in nature, asserting that 'because a pattern of organization has become established and survived, it must, therefore be efficient and/or perform a useful role for the overall economic system' (Whitley 2000:4) . The account presented above has indicated how the lineages of management are somewhat more complex. In particular they show the importance of antecedent cultural and social formations, formations which provided ideas and resources for developing new ways of organizing economic activity. In many ways what was most important was what was least recognised, those mundane, taken for granted practices which only become evident when set in comparative relief against practice elsewhere. The history of management has long been dominated by a focus on the growth of Scientific Management and images drawn from this are still dominant in much work on contemporary management (for a recent example, see Sewell 2005). However, this tends to concede too much to images of management as a 'rational' technical practice. We have seen how complex the exploration of a term like 'individualism' can be, but this genealogical practice is important in giving a sense of depth to contemporary discussions about management practice. If management practices are not merely rational responses to economic activity, invariant across time and space, then alternatives can be imagined. In a world in which particular forms of management activity are presented as universal, then such imagining is important.

\section{Acknowledgments}

My thanks to Yehouda Shenhav for comments on an earlier draft. Thanks also to participants in the sub-theme 'Managerial and Organizational Discourse in Time and Space' at the 21st EGOS Colloquium in Berlin, 2005 where an earlier version of this work was first discussed.

\section{References}


Anderson, R. 1985. In search of the 'lad of parts': the mythical history of Scottish education. History Workshop 19: 82-104.

Archer, M. 1996. Culture and agency: the place of culture in social theory. Cambridge: Cambridge University Press.

Blaikie, F. 1857. Inventory of personal estate of Robert Francis Blaikie of St Helens, Melrose d. 17 August 1857, Scottish Documents.com, [accessed 8 March 2005]

Broadie, A. 2001. The Scottish Enlightenment: The historical age of the historical nation. Edinburgh: Birlinn.

Broadie, A. 2003. The Cambridge companion to the Scottish Enlightenment. Cambridge: Cambridge University Press.

Brown, C. G. 1997. Religion and society in Scotland since 1707. Edinburgh: Edinburgh University Press.

Buchan, J. 2003. Capital of the mind: how Edinburgh changed the world. London: John Murray.

Calori, R., M. Lubatkin, and P. Very. 1998. The development of national collective knowledge in management. In Managerial and organizational cognition ed. C. Eden and J.-C. Spender, 147-167. London: Sage.

Camic, C. 1983. Experience and enlightenment: socialization for cultural change in eighteenth-century Scotland. Chicago: University of Chicago Press.

Campbell, J. 2000. The Anglo-Saxon state, London: Hambledon and London.

Carter, I. 1990. Ancient cultures of conceit: British university fiction in the post-war years. London: Routledge.

Chandler, A. D. 1962. 'Henry Varnum Poor, philosopher of management, 1812-1905'. In

Men in business ed W. Miller, 254-283. New York: Harper \& Row.

Clark, J. 2000. Protestantism, nationalism and national identity, 1660-1832. Historical

Journal 43(1): 249-276.

Colley, L. 2005. Britons: forging the nation 1707-1837. New Haven: Yale University

Press.

Colls, R. 2002. Identity of England. Oxford: Oxford University Press.

Daunton, M. J. 1989. “Gentlemanly capitalism” and British industry 1820-1914. Past and Present 122: 119-159.

Dobbin, F. 1994. Forging industrial policy: The United States, Britain, and France in the railway age. Cambridge: Cambridge University Press,

Duffy, E. 1992. The Stripping of the altars: Traditional religion in England 1400-1580.

New Haven, Ct: Yale University Press.

Duffy, E. 2001. The voices of Morebath: Reformation and rebellion in an English village. New Haven, Ct: Yale University Press.

Faith, R. 1997. The English peasantry and the growth of lordship. Leicester: Leicester University Press.

French, H. R., and R. W. Hoyle. 2003. English individualism refuted - and reasserted: The land market of Earls Colne Essex , 1550-1750'. Economic History Review, LVI( 4): 595622.

Ganter, H. and P Walgenbach. 2002. Middle managers: differences between Britain and Germany. In Challenges for European Management in a Global Context ed. M. Geppert, D. Matten and K. Williams, 165-188. Basingstoke: Palgrave Macmillan. 
Gantman, E. 2005. Capitalism, social privilege and managerial ideologies. Aldershot: Ashgate.

Grey, C. 2005. A very short, fairly interesting and reasonably cheap book about studying organizations. London: Sage.

Heal, F. and C. Holmes. 1994. The Gentry in England and Wales 1500-1700.

Basingstoke: Macmillan.

Herman, A. 2003. The Scottish Enlightenment: The Scots' invention of the modern world. London: Fourth Estate.

Hill, C. 1958. Puritanism and revolution. London: Secker \& Warburg.

Hollister, C. W. 1986. Monarchy, magnates and institutions in the Anglo-Norman world. London: The Hambledon Press.

Jeremy, D. 1988. Business and religion in Britain. Aldershot: Gower.

Jeremy, D. 2004. James Montgomery.Dictionary of national biography, 858-9. Oxford:

Oxford University Press.

Jones, G. 2000. Merchants to multinationals: British trading companies in the nineteenth and twentieth centuries. Oxford: Oxford University Press.

Lambert, S. 1975. House of Commons sessional papers of the Eighteenth Century, Vol 78, Reports of the Commissioners of Land Revenue, 12-17, 1792-93. Wilmington, Delaware: Scholarly Resources.

Lane, C. 1995. Industry and society in Europe: stability and change in Britain, Germany and France. Aldershot: Edward Elgar.

Law, B. 1995. Fieldens of Todmorden: a nineteenth century business dynasty, Littleborough: George Kelsall.

Macfarlane, A.. 1978 The Origins of English individualism: The family, property and social transition. Oxford: Blackwell.

Marshall, G. 1980. Presbyteries and profits: Calvinism and the development of capitalism in Scotland, 1560-1707. Oxford: Clarendon Press.

McCrone, D. 2005. Cultural capital in an understated nation: the case of Scotland. British Journal of Sociology, 56(1): 65-82.

Mepham, M. J. 1994. The Scottish Enlightenment and the Development of Accounting. In Accounting History: Some British Contributions ed. R. Parker and B. Yarney, 268296. Oxford: Oxford University Press.

Miller, H. 1853. First Impressions of England and its people. Edinburgh: Johnstone and Hunter.

Moody, M. 1975. 'Religion in the life of Charles Middleton, first Baron Barham'. In The Dissenting Tradition: essays for Leland H. Carlson ed. C. R. Cole and M. E. Moody, 140-163. Athens, Ohio: Ohio University Press.

Morgan, D. A. 1986. The individual style of the English gentleman. In Gentry and Lesser Nobility in Late Medieval Europe. Ed. M. Jones, 15-35. Gloucester: Alan Sutton. Morris, R. 2004. Charles Middleton, first Baron Barham, Dictionary of national biography, 46-49. Oxford: Oxford University Press.

Muldrew, C. 1998. The Economy of obligation: The culture of credit and social relations in early modern England, Basingstoke: Macmillan.

Mutch, A. 2005a. Management practice and kirk sessions: an exploration of the Scottish contribution to management. Journal of Scottish Historical Studies, 24(1): 1-19. 
Mutch, A 2005b. Strategic and organizational change: From production to retailing in UK brewing 1950-1990. London: Routledge.

Mutch, A. 2006. Public houses as multiple retailing: Peter Walker \& Son 1846-1914.

Business History, 48(1): 1-17.

Neale, G. 2004. Talking English. BBC History, November: 20-2.

Parker, R. 1975. Coke of Norfolk: a financial and agricultural study 1707-1842. Oxford: Clarendon.

Pryor, F. 2004. Britain AD: a quest for Arthur, England, and the Anglo-Saxons. London: HarperCollins.

Ransome, P. 2005. Work, consumption and culture: Affluence and social change in the twenty-first century. London: Sage.

Richards, E. 1973. The Leviathan of Wealth: The Sutherland fortune in the Industrial Revolution. London: Routledge \& Kegan Paul.

Richards, E. and M. Clough. 1989. Cromartie: Highland life 1650-1914. Aberdeen: Aberdeen University Press.

Richards, E. 2004. James Loch. Dictionary of National Biography, 209-11. Oxford:

Oxford University Press.

Robbins, K. 1988. Nineteenth-century Britain: intgration and diversity. Oxford:

Clarendon.

Robbins, K. 1998. Great Britain: identities, institutions and the idea of Britishness.

London: Longman.

Rodger, N. A. 2004. The Command of the Ocean: a naval history of Britain 1649-1815.

London: Allen Lane.

Rosie, G. 2004. Curious Scotland: tales from a hidden history. London: Granta.

Sewell, G. 2005. Nice work? Rethinking managerial control in an era of knowledge work. Organization, 12(5): 685-704.

Skinner, A. S. 1979. A System of social science: Papers relating to Adam Smith. Oxford: Clarendon.

Spraakman, G. and J. Margret. 2005. 'The transfer of management accounting practices from London counting houses to the British North American fur trade'. Accounting,

Business and Financial History, 15(2): 101-119.

Spring, D. 1963. The English landed estate in the Nineteenth century: Its administration. Baltimore: John Hopkins Press.

Strawhorn, J. 1983. 750 Years of a Scottish school: Ayr Academy 1233-1983. Ayr:

Alloway Publishing.

Todd, M. 2002. The Culture of Protestantism in early modern Scotland. New Haven:

Yale University Press.

Torrance, J. 1978. Social class and bureaucratic innovation: the Commissioners for examining the Public Accounts, 1780-1787. Past and Present, 78: 56-81.

Ure, D. 1794. General view of the agriculture of the county of Roxburgh with

observations on the means of its improvement. London: Board of Agriculture.

Wall, J. 1970. Andrew Carnegie. New York: Oxford University Press.

Whitley, R. 2000. Divergent capitalisms: The social structuring and change of business systems. Oxford: Oxford University Press.

Whittle, J. 2003. Development of agrarian capitalism: Land and labour in Norfolk 14401580. Oxford: Clarendon. 
Whyman, S. E. 1999. Sociability and power in late Stuart England: The cultural world of the Verneys 1660-1720. Oxford: Oxford University Press.

Wood, M. 2000. In search of England: Journeys into the English past. London: Penguin.

\footnotetext{
${ }^{1}$ Feuing allowed the purchase of feudal charters for a high initial price and subject to a nominal continuing payment ('feu duty'), thus creating effective ownership and control of land

${ }^{2}$ I have tried to suggest the long term consequences of this process in my Strategic and Organizational Change: from production to retailing in UK brewing 1950-1990 (Mutch 2005). Whilst this account concentrates on changes in the post-war period, it is set in the longer term history of managerial practices; one would suggest that it is often hard to see how contemporary management takes the form that it does without such a longer perspective.

${ }^{3}$ Joseph Wall (1970) points the essentially political (as opposed to economic) nature of the 'moral force' Chartism that Carnegie grew up with in Dunfermline. In such a creed the focus became entirely on the removal of hereditary privilege; once removed, the focus could be on 'rational' management. That this might not remove (and indeed, might deepen) other forms of inequality was not a central concern. In this way elements of a politically democratic and, in its context, radical approach might pave the way for forms of management.
} 